\title{
Effect of estrogen on bone resorption and inflammation in the temporomandibular joint cellular elements
}

\author{
NADIA GALAL ${ }^{1-3}$, WALEED EL BEIALY ${ }^{1,3}$, YOSHIAKI DEYAMA ${ }^{2}$, YOSHITAKA YOSHIMURA ${ }^{2}$, \\ TETSUYA YOSHIKAWA ${ }^{1}$, KUNIAKI SUZUKI ${ }^{2}$ and YASUNORI TOTSUKA ${ }^{1}$ \\ Departments of ${ }^{1}$ Oral and Maxillofacial Surgery and ${ }^{2}$ Molecular Cell Pharmacology, Hokkaido University \\ Graduate School of Dental Medicine, Hokkaido, Japan; ${ }^{3}$ Department of Oral and Maxillofacial Surgery, \\ Faculty of Oral and Dental Medicine, Cairo University, Cairo, Egypt
}

Received January 25, 2008; Accepted February 28, 2008

\begin{abstract}
Several epidemiological studies have reported that temporomandibular disorder is more prevalent in women, which suggests the involvement of sex hormones, such as estrogen, in the pathogenesis of this disease. PCR amplification and Western blotting were employed to target the expression of estrogen receptors (ERs) in human fibroblast-like synovial and ATDC5 cells. The effect of estrogen was investigated through the expression of RANKL, osteoprotegerin (OPG), $\mathrm{M}-\mathrm{CSF} / \mathrm{CSF}-1$ and c-fms. We showed expression of M-CSF/ CSF-1 and c-fms, with time-dependent increase in both after the addition of estrogen. Based on previous studies reporting that M-CSF/CSF-1 regulates the proliferation and differentiation of hemopoietic progenitor cells into mature macrophages, we put forward a new hypothesis based on the increased inflammation and tendency of females to suffer more from temporomandibular disorder (TMD) in the presence of external exacerbating factors. Detection of RANKL and OPG in ATDC5 and expression of both in HFLS was confirmed with complete disappearance of the RANKL band, and marked increase in the expression of OPG after $1 \mathrm{~h}$ from the addition of estrogen.
\end{abstract}

\section{Introduction}

Estrogen, a representative steroid hormone, is known to regulate diverse physiological processes of target tissues, in both sexes (1). The biological activities of estrogen are initiated by binding to the specific receptor proteins, namely the estrogen receptors (ERs) (2). Two main isoforms of ER have been identified to date: ER $\alpha$ and $ß$. Immunocytochemistry

Correspondence to: Dr Yoshiaki Deyama, Department of Molecular Cell Pharmacology, Hokkaido University Graduate School of Dental Medicine, Kita-ku, Kita 13, Nishi 7, Sapporo, Hokkaido, Japan

E-mail: dey@den.hokudai.ac.jp

Key words: Temporomandibular disorder, macrophage colonization, osteoprotegerin, MCSF using specific antibodies has revealed that ER $\alpha$ is widely distributed in various tissues, whereas the definitive distribution of ER $\beta$ protein remains unclear (2).

The steroid nuclear receptors are a sub-family of the NR (nuclear receptor) super family, mediating the cellular effects of steroid hormones. NR genes are typically found on the nuclear membrane or less frequently, free in the cell cytoplasm (3).

The temporomandibular joint (TMJ) is a bilateral diarthrosis between the mandibular condyle and temporal bone. Temporomandibular disorder (TMD) is characterized by a triad of symptoms, including joint sounds, pain, and limited mandibular movement (4). These symptomatic variants indicate that TMD is caused by a combination of factors, such as occlusion, mental stress, strength, and hormones; however, the etiology of this disease is not fully understood. Several epidemiological studies have reported that TMD is more prevalent in women than in men (5-7), which suggests the involvement of sex hormones, such as estrogen, in the pathogenesis of this disease. Although estrogen is known to play important roles in the etiology of postmenopausal osteoarthrosis or rheumatoid arthritis in systemic joints $(8,9)$, little information has been available regarding the relationship between estrogen and the etiology of TMD (10).

The synovial membrane in the TMJ has an important role in joint movement because of the involvement of the synovial lining cells in the synovial fluid metabolism, which affects smooth jaw movement. Many ultra structural investigations have pointed out that the synovial membrane consists of two kinds of synovial lining cells: macrophage-like type A and fibroblastic type B cells (11). However, little previous information is available regarding the localization of ER $\alpha$ and $B$ in the TMJ.

Macrophage colony-stimulating factor (M-CSF or CSF-1) is one of a family of acidic glycoproteins which regulate the survival, proliferation and differentiation of hemopoietic progenitor cells into mature macrophages and/or granulocytes (12). As its name implies, M-CSF/CSF-1 specifically promotes the growth and differentiation of cells in the monocytemacrophage lineage and activates various functions of mature macrophages (13-15). The c-fms gene encodes the receptor for macrophage colony-stimulating factor-1 (16). 
Table I. The sequences of the used primers.

\begin{tabular}{|c|c|c|}
\hline Primer & & Sequence \\
\hline \multirow[t]{2}{*}{ Mouse ER $\alpha$} & Forward & CAAGGAGGGAGTGCGTCTGG \\
\hline & Reverse & CATCTAGGACCAGGTCCTCAGC \\
\hline \multirow[t]{2}{*}{ Mouse ER ß } & Forward & TCTGCAGTGATTATGCATCTGGG \\
\hline & Reverse & CTTCGTGAGGGACATCATCATGG \\
\hline \multirow[t]{2}{*}{ Human ER $\alpha$} & Forward & AAGAGCTGCCAGGCCTGCC \\
\hline & Reverse & TTGGCAGCTCTCATGTCTCC \\
\hline \multirow[t]{2}{*}{ Human ER ß } & Forward & GCTCAATTCCAGTATGTACC \\
\hline & Reverse & GGACCACATTTTTGCACT \\
\hline \multirow[t]{2}{*}{ RANKL } & Forward & ACGCAGATTTGCAGGACTCGAC \\
\hline & Reverse & TTCGTGCTCCCTCCTTTCATC \\
\hline \multirow[t]{2}{*}{ OPG } & Forward & TGGCACACGAGTGATGAATGCG \\
\hline & Reverse & GCTGGAAAGTTTGCTCTTGCG \\
\hline \multirow[t]{2}{*}{$\mathrm{c}-f m s$} & Forward & GCG ATG TGT GAG CAA TGG CAG T \\
\hline & Reverse & AGA CCG TTT TGC GTA AGA CCT G \\
\hline \multirow[t]{2}{*}{ CSF-1 } & Forward & ATGACAGACAGGTGGAACTGCCAGTGTAGAGG \\
\hline & Reverse & TCACACAACTTCAGTAGGTTCAGGTGATGGGGC \\
\hline \multirow[t]{2}{*}{ G3PDH } & Forward & GTCTACATGTTCCAGTATGAC TCC \\
\hline & Reverse & AGCCTTCTCCATGGTGGTGAAGAC \\
\hline \multirow[t]{2}{*}{ B-actin } & Forward & TGACGGGGTCACCCACACTGTGCCCATCTA \\
\hline & Reverse & CTAGAAGCATTGCGGTGGACGATGGAGGG \\
\hline \multirow[t]{2}{*}{ L19 } & Forward & CTGAAGGTGAAGGGGAATGTG \\
\hline & Reverse & GGATAAAGTCTTGATGATCTC \\
\hline
\end{tabular}

RANKL (receptor activator of NFKB ligand) is a membrane-bound ligand expressed on osteoblasts. Binding of RANKL to its receptor RANK which is expressed on osteoclast precursors and mature osteoclasts, induces osteoclastogenesis and activation of mature osteoclasts (17-21). RANK is a member of TNF receptor super family, expressed as a transmembrane heterotrimer on the surface of haematopoietic osteoclasts progenitors, mature osteoclasts, chondrocytes, mammary gland epithelial cells (22-26). Estrogen has been shown to suppress RANKL-induced osteoclast differentiation in vitro (27).

Osteoprotegerin (OPG), a soluble tumor necrosis factor (TNF) receptor-like molecule termed TNF receptor super family $11 \mathrm{~B}$, is a naturally occurring RANKL inhibitor. OPG competitively binds RANKL to inhibit the action of the receptor activator of NFKB (RANK) both in vivo and in vitro, which prevents osteoclastic bone resorption (28).

Our study targets the expression of ERs in normal human fibroblast-like synovial cells (HFLS) and ATDC5 (as a model for chondrocytes) and thus the effect of estrogen on synovial membrane fibroblastic type B cells represented by HFLS and chondrocytes represented by ATDC5 cells as regarding inflammation and bone resorption.

\section{Materials and methods}

Cell culture. HFLS are primary human fibroblast-like synovial cells, from synovial membrane of a 67-year old Caucasian female, were purchased from (Cell Applications, Inc., San Diego, CA) and cultured in Synoviocyte Growth Medium (Cell Applications). ATDC5 (differentiate into chondrocytes), were purchased from RIKEN Cell Bank and cultured in DMEM: HamF12 =1:1 (Sigma-Aldrich, St. Louis, MO), with 5\% FBS. Cells were incubated in humidified $5 \% \mathrm{CO}_{2}$ atmosphere at $37^{\circ} \mathrm{C}$.

Exogenous $17 \beta$-estradiol treatment. At confluence $\left(10^{-11} \mathrm{M}\right)$, 17ß-estradiol (in ethanol, Sigma-Aldrich) was added to the medium for periods of $1,3,6,12$ and $24 \mathrm{~h}$, while controls were treated with an equivalent volume of ethanol (estrogen vehicle).

Reverse transcription (RT)-polymerase chain reaction (PCR). Total RNA was isolated using guanidinium thiocyanatephenol-chloroform extraction (TRIzol, Invitrogen Corp., Carlsbad, CA). The RNA pellets were dissolved in distilled water and quantified using spectrophotometer (NanoDrop Tech., Inc., Wilmington, DE). Total RNA was reverse transcribed using oligo-(dT) primers and reverse transcriptase (Toyobo, Tokyo, Japan) according to the manufacturer's protocol.

PCR amplification: ER $\alpha$ and $B$ were amplified with KODDash (Toyobo). At first, gene-specific primers for human glyceraldehyde-3-phosphate dehydrogenase (G3PDH) were used to test cDNA quality. Amplification was performed as follows: 35 cycles at $94^{\circ} \mathrm{C}$ for $30 \mathrm{sec}$, annealing at $60^{\circ} \mathrm{C}$ for 


\section{Protein}

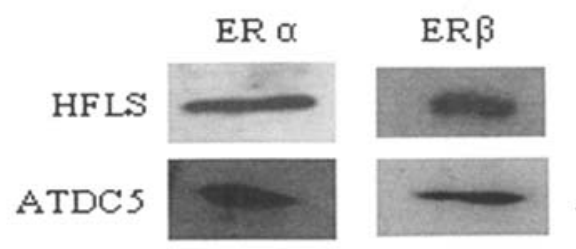

$\underline{\text { mRNA }}$

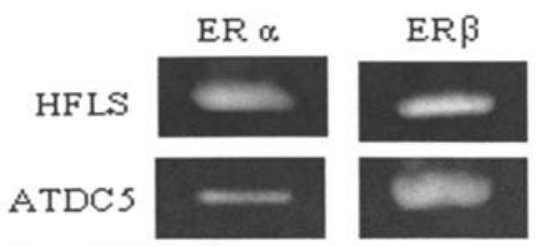

Figure 1. Right panels, estrogen receptors $\alpha$ and $\beta$ RNA expression in HFLS and ATDC5 cells. Cells were analyzed by RT-PCR for the presence of the mRNA encoding ER $\alpha$ and $B$. Cells were cultured in standard growth conditions; RNA was extracted and retro-transcribed using the reverse transcriptase enzyme (RT). ER $\alpha$ and $\beta$ were expressed as specific single bands. Left panels, Western blot analysis for ERs: the whole cell lysates from HFLS and ATDC5 were analyzed for the expression of ER $\alpha$ and $\beta$. The positive controls were MCF7 whole cell lysate for $\alpha$ and NIH/3T3 whole cell lysate for ß. Cont, control.

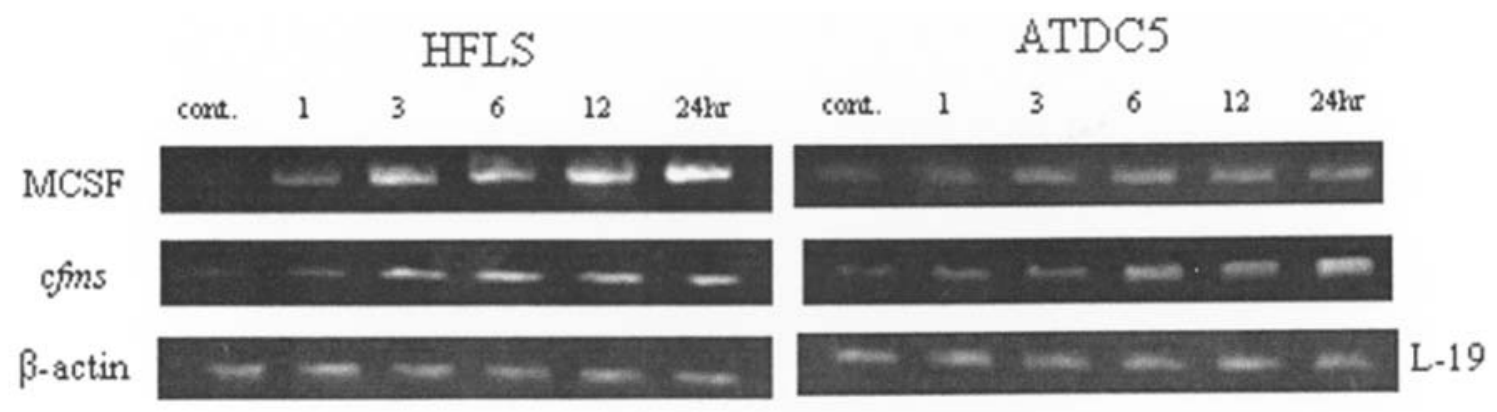

Figure 2. The effect of $17 ß$-estradiol on MCSF and c-fms mRNA expression in HFLS and ATDC5. Cells were incubated with $10^{-11}$ M 173 -estradiol for periods of 1, 3, 6, 12 and $24 \mathrm{~h}$. RNA was isolated and RT-PCR was performed. There was a gradual increase in expression of M-CSF/CSF-1 and c-fms after $1 \mathrm{~h}$. Cont, control.

$2 \mathrm{sec}$ and $72^{\circ} \mathrm{C}$ for $30 \mathrm{sec}$. The first cycle was conducted at $94^{\circ} \mathrm{C}$ for $10 \mathrm{~min}$ and the final cycle at $72^{\circ} \mathrm{C}$ for $10 \mathrm{~min}$.

For c-fms, M-CSF/CSF-1, RANKL and OPG, PCR was run for 27, 35, 28 and 25 cycles, respectively using Ampli-Tag Gold DNA polymerase (Perkin-Elmer, Boston, MA). Genespecific primers for L19 and $B$-actin were used to test cDNA quality and equalization. Amplification was performed as follows: $95^{\circ} \mathrm{C}$ for $1 \mathrm{~min}$, annealing at $58^{\circ} \mathrm{C}$ and $72^{\circ} \mathrm{C}$ for $1 \mathrm{~min}$. The first cycle was conducted at $95^{\circ} \mathrm{C}$ for $11 \mathrm{~min}$ and the final cycle at $72^{\circ} \mathrm{C}$ for $10 \mathrm{~min}$. The sequences of the used primers are as shown in Table I.

Following PCR, the reaction products were resolved on $2 \%$ agarose gel by electrophoresis. Gel was stained with ethidium bromide to visualize the PCR products. The levels of expression were analyzed with Image J $1.37 \mathrm{v}$ (Rasband, W.S., ImageJ, US National Institutes of Health, Bethesda, MD, USA) and normalized with G3PDH, L19 and B-actin mRNA expression (data not shown).

Western blotting. For protein extraction, at confluence, media were aspirated, cells were washed with Dulbecco's phosphatebuffered saline (PBS) without calcium and magnesium (1X PBS), and lysis buffer was added (10 mM HEPES-KOH at $\mathrm{pH} 7.5,100 \mathrm{mM} \mathrm{KCl}, 0.1 \% \mathrm{NP}-40)$. Cells were lysed thoroughly and dislodged from plate by repetitive pipetting. Protein concentrations were assessed by Bio-Rad protein assay kit. Controls for both $\alpha$ and $\beta$ were used (MCF7 whole cell lysate for $\alpha$ and NIH/3T3 whole cell lysate for $\beta$, Santa Cruz Biotechnology, Inc., CA). Samples were separated on $10 \%$ polyacrylamide gels and transferred onto polyvinylidene difluoride membranes. Membranes were blocked for $1 \mathrm{~h}$ in $5 \%$ skim milk followed by 3 washings with TBS containing $0.1 \%$ Tween buffer and were placed in a primary antibody [1:200 ER $\alpha(\mathrm{H}-184)$ rabbit polyclonal IgG and 1:500 ER B rabbit polyclonal $\mathrm{IgG}$, Santa Cruz Biotechnology] overnight at $4^{\circ} \mathrm{C}$ on shaker, followed by 3 washings with TBST and placed in secondary antibody (1:2500 HRP-goat anti-rabbit $\mathrm{IgG}$, Zymed, San Francisco, CA) for $1 \mathrm{~h}$ at room temperature on shaker. After 3 washings for $15 \mathrm{~min}$, the membranes were incubated in Western Lightning Chemiluminescence reagent Plus (Perkin-Elmer). Medical X-ray film was used to visualize the chemiluminescence.

\section{Results}

Expression of ERs. ERs are central to the study, so we examined the expression of ER $\alpha$ and $\beta$ in HFLS and ATDC5 cells. Using PCR (35 cycle amplification) both ER $\alpha$ and $B$ were expressed as a specific single band in HFLS and ATDC5 cells (Fig. 1). Further more, Western blotting confirmed the expression of both ER $\alpha$ and $\beta$ in both cells (Fig. 1).

Expression of $M-C S F / C S F-1$ and c-fms and effect of estrogen in HFLS and ATDC5. PCR amplification for 35, 27 cycles respectively, showed novel expression of $\mathrm{M}-\mathrm{CSF} / \mathrm{CSF}-1$ and c-fms in HFLS and ATDC5 cells (Fig. 2). At confluence, following addition of $10^{-11} \mathrm{M} 173$-estradiol (in ethanol) to the medium for periods of $1,3,6,12$ and $24 \mathrm{~h}$, the effect of estrogen on M-CSF/CSF-1 and c-fms in HFLS and ATDC5 was investigated. PCR amplification for 35, 27 cycles 
HFLS

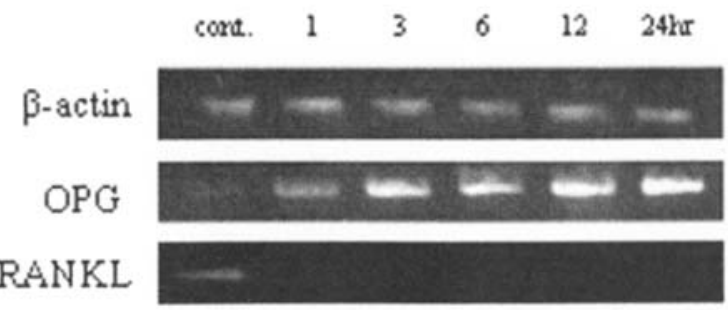

ATDC5

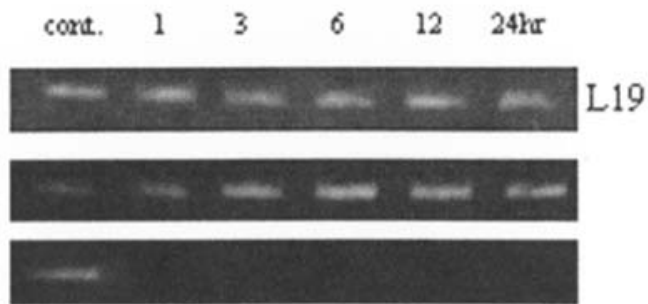

Figure 3. The effect of 17ß-estradiol on RANKL and OPG mRNA expression in HFLS and ATDC5. Cells were incubated with 10-11 M 17ß-estradiol for periods of 1,3,6, 12 and $24 \mathrm{~h}$. RNA was isolated and RT-PCR was performed. There was marked increase in the expression of OPG and complete disappearance of the RANKL band, after $1 \mathrm{~h}$. Cont, control.

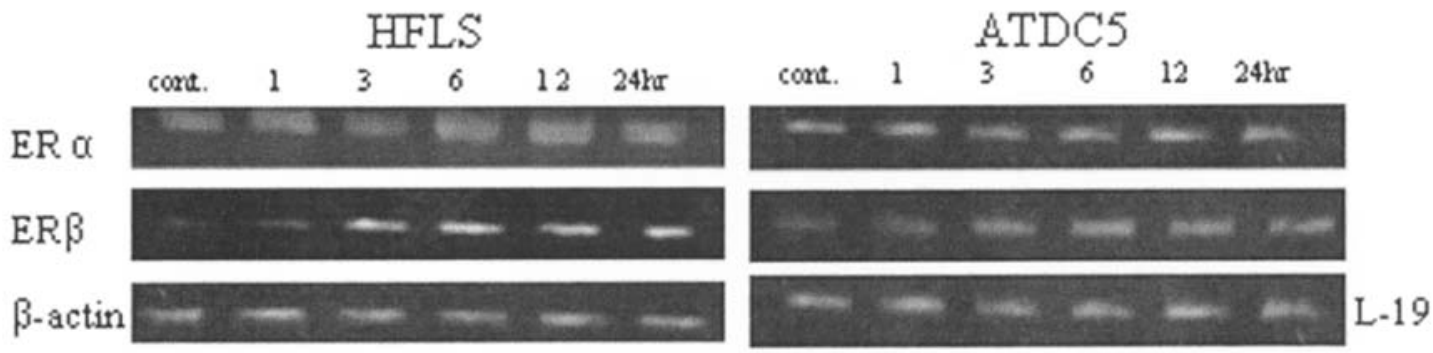

Figure 4. The effect of 17ß-estradiol on ER $\alpha$ and $\beta$ mRNA expression in HFLS and ATDC5 cells. Cells were incubated with $10^{-11} \mathrm{M} 17 \beta$-estradiol for periods of $1,3,6,12$ and $24 \mathrm{~h}$. RNA was isolated, and RT-PCR was performed. A gradual increase in expression of ER $\beta$ with time was observed, with no change occurring to the expression of ER $\alpha$. Cont, control.

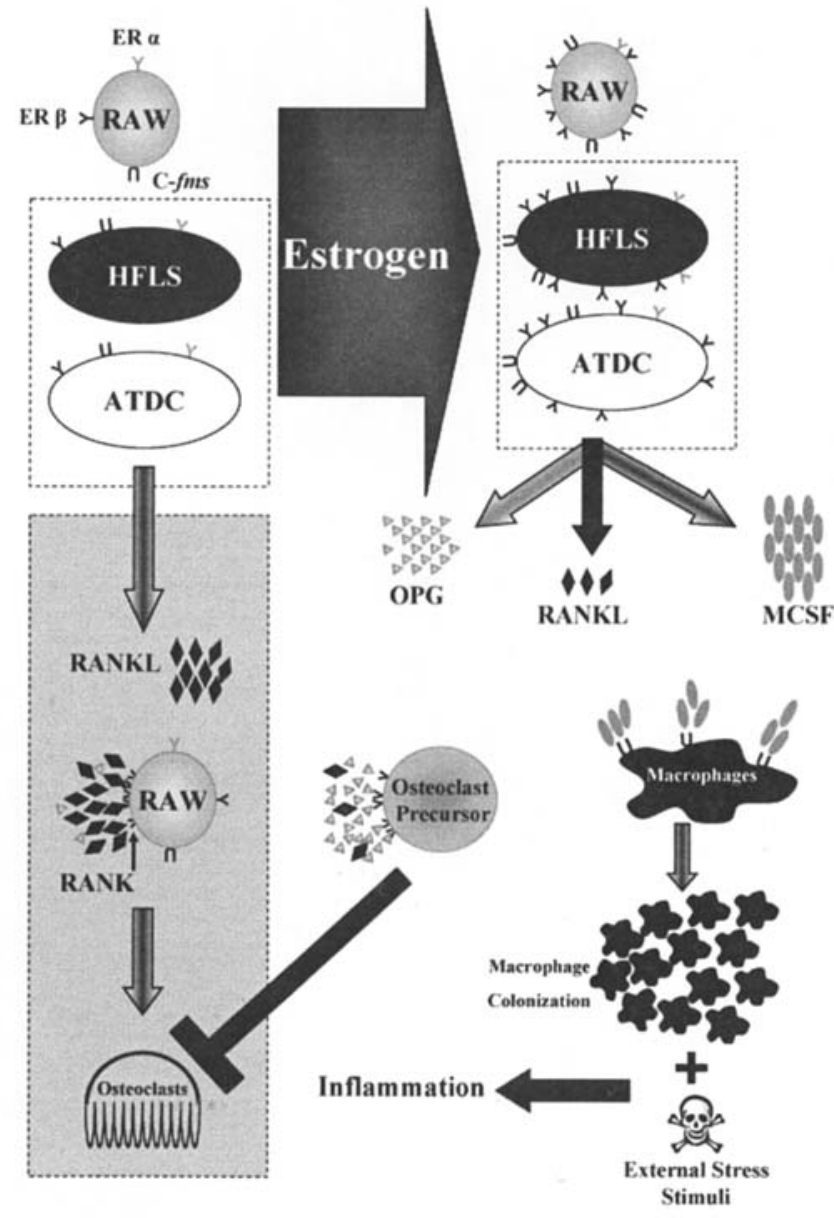

respectively, showed time-dependent increase in expression of M-CSF/CSF-1 and c- $f m s ~ 1 \mathrm{~h}$ after the addition of estrogen (Fig. 2). Same result was obtained in both cell types (Fig. 2).

Expression of RANKL and OPG and the effect of estrogen. Novel detection of RANKL and OPG in ATDC5 and expression of both in HFLS was confirmed by PCR amplification for 28 and 25 cycles respectively. At confluence, following addition of $10^{-11} \mathrm{M} 173$-estradiol (in ethanol) to the medium, PCR amplification revealed complete disappearance of the RANKL band, with marked increase in the expression of OPG after $1 \mathrm{~h}$ from the addition of estrogen, with a continuous time-dependent increase of expression (Fig. 3). Same result was obtained in both cell types.

Effect of estrogen on ER $\alpha$ and $\beta$ receptors. The capacity of estrogen to increase expression of M-CSF/CSF-1, c-fms, and OPG, and diminishing the expression of RANKL, together with the detection of ERs in both cells suggested mediation

Figure 5. Estrogen increases inflammation and decreases bone resorption. The HFLS, ATDC5 and RAW 264.7 cells show increase in expression of ER $B$ after the addition of estrogen. HFLS and ATDC5 express RANKL that helps the differentiation of osteoclast precursors into osteoclasts. However with the addition of estrogen, there is diminished expression of RANKL and up-regulated expression of OPG that binds to RANKL, blocking the interaction between RANKL and RANK. Estrogen increases MCSF expression, causing proliferation and differentiation of macrophages. When chronically or erroneously stimulated, macrophages exert damaging effects on the surrounding tissue (inflammation). 
by ERs (ER $\alpha$ or $\beta$ ) so we studied the effect of estrogen on ERs. The expression of both ER $\alpha$ and $\beta$ after addition of $10^{-11} \mathrm{M} 173$-estradiol for periods of $1,3,6,12$ and $24 \mathrm{~h}$ was studied. PCR amplification of 35 cycles was conducted for both ERs. For HFLS and ATDC5, there was a gradual increase in expression of ER $\beta$ with time, with no change occurring to the expression of ER $\alpha$ (Fig. 4).

\section{Discussion}

Although many epidemiological studies have reported a higher frequency of TMD in females than in males (5-7), there has been controversy concerning the presence of ERs in the TMJ. Abubaker et al (29) found ER $\alpha$ immunoreactivity in the articular disc of human TMJs; however, Campbell et al (5) found no such immunoreactivity in the articular disc of a TMJ obtained from a TMD patient. In our previous study (30), with the use of Western blotting and PCR amplification, we were able to demonstrate the novel detection of ER $B$ and confirmed presence of ER $\alpha$ in RAW 264.7 cells (representing macrophage-like type A synovial linning cells). In this study we showed expression of ER $\alpha$ and $\beta$ in HFLS (synovial linning cells type B), thus exploring both kinds of synovial lining cells.

The effects of estrogen on bone metabolism are well established. In contrast, there have been few studies regarding the effect of estrogen on cartilage in the TMJ, or even in other systematic joints (31). To have an overview of all joint cellular elements, we investigated and confirmed the presence of ER $\alpha$ and $B$ in ATDC5 cells (as a model for chondrocytes), denoting possible estrogen effects on joint cells through these receptors.

In our previous study (30) we showed that estrogen increased expression of c-fms in macrophage-like cells. In the present study, we detected the expression of M-CSF/CSF-1 and c-fms in ATDC5 and HFLS cells and we further demonstrated increased expression of M-CSF/CSF-1 and c-fms via estrogen. Based on previous studies reporting that $\mathrm{M}-\mathrm{CSF} / \mathrm{CSF}-1$ regulates the survival, proliferation and differentiation of hemopoietic progenitor cells into mature macrophages and/or granulocytes (12), and as M-CSF/CSF-1 increased via estrogen, we hypothesize a resultant increase in macrophage colonization (Fig. 5). Macrophages are patrolling cells of the innate immunity, involved in the recognition of foreign pathogens, in the elimination of toxic molecules and in the reconstitution of tissue integrity. Macrophage cells orchestrate these diverse pathways by producing several different mediators, such as nitric oxide (NO), cytokines, including interleukin $1 \beta$ (IL-1ß) and tumor necrosis factor- $\alpha$ $(\mathrm{TNF} \alpha)$, and matrix degrading enzymes, such as metalloprotease-9 (MMP-9). The production of these molecules, although beneficial for killing bacteria and further activating the immune system, exerts damaging effects on the surrounding tissue when chronically or erroneously stimulated (32). Thus, in the presence of external exacerbating factors such as stress, the increase in macrophage colonization could be a contributing factor in the increased inflammation and tendency of females to suffer more from TMD.

Until recently, inflammatory cytokines, such as interleukin (IL)-1, IL-6, IL-11, and TNF- $\alpha$ were implicated as important mediators of bone lysis (33-35). Recent findings, however, indicate that RANKL might be the central mediator of osteoclast development in bone loss pathologies. RANKL expressed on synovial fibroblasts and activated T-lymphocytes enhance differentiation of synovial macrophages and osteoclast precursors in bone marrow into bone resorbing osteoclasts (20). Using PCR we showed expression of RANKL and OPG in HFLS and their novel detection in ATDC5. In contrast to other studies stating that estrogen does not have any effect on RANKL, we can show that after $1 \mathrm{~h}$ from the addition of $17 ß$-estradiol there is completely diminished expression of RANKL with an enhanced expression of OPG.

We hereby show that estrogen prevents bone resorption by up-regulating OPG production to increase OPG binding of RANKL, which subsequently blocks the interaction between RANKL and RANK in osteoclasts (Fig. 5).

Estrogens have been demonstrated to act via ER $B$ in tissues of the central nervous system, cardiovascular system, immune system, urogenital tract, gastrointestinal tract, kidney and lungs (36). The capacity of estrogen to increase expression of MCSF, c-fms, and OPG, and diminishing the expression of RANKL, together with the detection of ERs in HFLS and ATDC5 cells suggested mediation by ERs (ER $\alpha$ or $\beta$ ). So we studied the effect of estrogen on ERs. For HFLS and ATDC5, there was a gradual increase in expression of ER $B$ with time, with no change occurring to the expression of ER $\alpha$. This coincides with our previous study showing increase in expression of ER $\beta$ in RAW 264.7 cells following application of $17 ß-$ estradiol and the shown relation between receptor expression and different estrogen concentrations.

Exploring various cellular elements, showing presence of estrogen receptors $\alpha$ and $\beta$, and presenting the coexisting relation between estrogen and ER $\beta$ denotes possible estrogen effects on joint cells through these receptors. Referring to the increased expression of M-CSF/CSF-1 and c-fms we hypothesize increased macrophage colonization to be a contributing factor in the increased inflammation and tendency of females to suffer more from TMD in the presence of external exacerbating factors. An attempt to scientifically explain female tendency to TMD, may provide novel targets of both prevention and therapy.

\section{References}

1. Galand P, Leroy F and Chretien J: Effect of estradiol on cell proliferation and histological changes in the uterus and vagina of mice. J Endocrinol 49: 243-252, 1971.

2. Pavao M and Traish AM: Estrogen receptor antibodies: specificity and utility in detection, localization and analyses of estrogen receptor $\alpha$ and $\beta$. Steroids 66: 1-16, 2001.

3. Fryer CJ, Kinyamu HK, Rogatsky I, Garabedian MJ and Archer TK: Selective activation of the glucocorticoid receptor by steroid antagonists in human breast cancer and osteosarcoma cells. J Biol Chem 275: 17771-17777, 2000.

4. Kuttila M, Niemi PM, Kuttila S, Alanen P and Le Bell Y: TMD treatment need in relation to age, gender, stress, and diagnostic subgroup. J Orofac Pain 12: 67-74, 1998.

5. Campbell JH, Courey MS, Bourne P and Odziemiec C: Estrogen receptor analysis of human temporomandibular disc. J Oral Maxillofac Surg 51: 1101-1105, 1993.

6. Le Resche L: Epidemiology of temporomandibular disorders: implications for the investigation of etiologic factors. Crit Rev Oral Biol Med 8: 291-305, 1997.

7. Kapila S and Xie Y: Targeted induction of collagenase and stromelysin by relaxin in unprimed and beta-estradiol-primed diarthrodial joint fibrocartilaginous cells but not in synoviocytes. Lab Invest 78: 925-938, 1998. 
8. Ushiyama $\mathrm{T}$, Inoue $\mathrm{K}$ and Nishioka $\mathrm{J}$ : Expression of estrogen receptor related protein (p29) and estradiol binding in human arthritic synovium. J Rheumatol 22: 421-426, 1995.

9. Khalkhali-Ellis Z, Seftor EA, Nieva DR, Handa RJ, Price RH Jr, Kirschmann DA, Baragi VM, Sharma RV, Bhalla RC, Moore TL and Hendrix MJ: Estrogen and progesterone regulation of human fibroblast-like synoviocytes function in vitro: implications in rheumatoid arthritis. J Rheumatol 27: 1622-1631, 2000.

10. Warren MP and Fried JL: Temporomandibular disorders and hormones in women. Cells Tissues Organs 169: 187-192, 2001.

11. Barland P, Novikoff $A B$ and Hamerman D: Electron microscopy of the human synovial membrane. J Cell Biol 14: 207-220, 1962.

12. Morstyn $\mathrm{G}$ and Burgess AW: Hemopoietic growth factors: a review. Cancer Res 48: 5624-5637, 1988.

13. Hamilton JA, Stanley ER, Burgess AW and Shadduck RK: Stimulation of macrophage plasminogen activator activity by colony-stimulating factors. J Cell Physiol 103: 435-445, 1980.

14. Wing EJ, Ampel NM, Waheed A and Shadduck RK: Macrophage colony-stimulating factor (M-CSF) enhances the capacity of murine macrophages to secrete oxygen reduction products. J Immunol 135: 2052-2056, 1985.

15. Warren MK and Ralph P: Macrophage growth factor CSF-1 stimulates human monocyte production of interferon, tumor necrosis factor, and colony stimulating activity. J Immunol 137: 2281-2285, 1986

16. Fuller K, Owens JM, Wilson A, Moss R and Chambers TJ: Macrophage colony-stimulating factor stimulates survival and chemotactic behavior in isolated osteoclasts. J Exp Med 178: 1733-1744, 1993.

17. Lacey DL, Timms E, Tan HL, Kelly MJ, Dunstan CR, Burgess T, Elliot R, Colombero A, Elliot G, Scully S, Hsu H, Sullivan J, Hawkins N, Davy E, Capparelli C, Elli A, Qian YX, Kaufman S, Sarosi I, Shalhoub V, Senaldi G, Guo J, Delany J and Boyle WJ: Osteoprotegerin ligand is a cytokine that regulates osteoclast differentiation and activation. Cell 93: 165-176, 1998.

18. Kong YY, Yoshida H, Sarosi I, Tan HL, Timms E, Capparelli C, Morony S, Oliveira-dos-santos AJ, Van G, Itei A, Khoo W, Wakeham A, Dunstan CR, Lacey DL, Mak TW, Boyle WJ and Penninger JM: OPGL is a key regulator of osteoclastogenesis, lymphocyte development and lymph-node organogenesis. Nature 397: 315-323, 1999.

19. Simonet WS, Lacey DL, Dunstan CR, Kelly MJ, Chang MS, Luthy R, Nguyen HQ, Wooden S, Bennett L, Boone T, Shimamoto G, DeR ose M, Elliot R, Colombero A, Tan HL, Trail G, Sullivan J, Davy E, Bucay N, Renshaw-Gegg L, Hughes TM, Hill D, Pattison W, Campbell P, Sander S, Van G, Tarpley J, Derby P, Lee R and Boyle WJ: Osteoprotegerin a novel secreted protein involved in the regulation of bone density. Cell 89: 309-319, 1997

20. Mitani M, Miura Y, Saura R, Kitagawa A, Fukuyama T, Hashiramoto A, Shiozawa S, Kurosaka M and Yoshiya S: Estrogen specifically stimulates expression and production of osteoprotegerin from rheumatoid synovial fibroblasts. Int J Mol Med 15: 827-832, 2005.

21. Wong BR, Rho J, Arron J, Robinson E, Orlinick J, Chao M, Kalachikov S, Cayani E, Bartlett FS, Frankel WN, Lee SY and Choi Y: TRANCE is a novel ligand of the tumor necrosis factor receptor family that activates c-Jun $\mathrm{N}$-terminal kinase in $\mathrm{T}$ cells. J Biol Chem 272: 25190-25194, 1997.

22. Fata JE, Kong YY, Li J, Sasaki T, Irie-Sasaki J, Moorehead RA, Elliott R, Scully S, Voura EB, Lacey DL, Boyle WJ, Khokha R and Penninger JM: The osteoclast differentiation factor osteoprotegerin-ligand is essential for mammary gland development. Cell 103: 41-50, 2000.
23. Lum L, Wong BR, Josien R, Becherer JD, Erdjument-Bromage H, Schlöndorff J, Tempst P, Choi Y and Blobel CP: Evidence for a role of a tumor necrosis factor-alpha (TNF-alpha) converting enzyme-like protease in shedding of TRANCE, a TNF family member involved in osteoclastogenesis and dendritic cell survival. J Biol Chem 274: 13613-13618, 1999.

24. Nakashima T, Kobayashi Y, Yamasaki S, Kawakami A, Eguchi K, Sasaki $\mathrm{H}$ and Sakai H: Protein expression and functional difference of membrane-bound and soluble receptor activator of NF-kappaB ligand: modulation of the expression by osteotropic factors and cytokines. Biochem Biophys Res Commun 275: 768-775, 2000.

25. Kartsogiannis V, Zhou H, Horwood NJ, Thomas RJ, Hards DK, Quinn JM, Niforas P, Ng KW, Martin TJ and Gillespie MT: Localization of RANKL (receptor activator of $\mathrm{NF}_{\kappa} \mathrm{B}$ ligand) mRNA and protein in skeletal and extraskeletal tissues. Bone 25: 525-534, 1999.

26. Lagasse E and Weissman IL: Enforced expression of Bcl-2 in monocytes rescues macrophages and partially reverses osteopetrosis in op/op mice. Cell 89: 1021-1031, 1997.

27. Shevde NK, Bendixen AC, Dienger KM and Pike JW: Estrogens suppress RANK ligand-induced osteoclast differentiation via a stromal cell independent mechanism involving c-Jun repression. Proc Natl Acad Sci USA 97: 7829-7834, 2000.

28. Villa I, Mrak E, Rubinacci A, Ravasi F and Guidobono F: CGRP inhibits osteoprotegerin production in human osteoblast-like cells via cAMP/PKA-dependent pathway. Am J Physiol Cell Physiol 291: 529-537, 2006

29. Abubaker AO, Raslan WF and Sotereanos GC: Estrogen and progesterone receptors in temporomandibular joint discs of symptomatic and asymptomatic persons: a preliminary study. J Oral Maxillofac Surg 51: 1096-1100, 1993.

30. Galal N, El-Beialy WR, Deyama Y, Yoshimura Y, Suzuki K and Totsuka Y: Novel effect of estrogen on RANK and c-fms in RAW 264.7 cells. Int J Mol Med 20: 97-101, 2007.

31. Claassen H, Hassenpflug J, Schunke M, Sierralta W, Thole H and Kurz B: Immunohistochemical detection of estrogen receptor $\alpha$ in articular chondrocytes from cows, pigs and humans: in situ and in vitro results. Ann Anat 183: 223-227, 2001.

32. Palacios VG, Robinson LJ, Borysenko CW, Lehmann T, Kalla SE and Blair HC: Negative regulation of RANKL-induced osteoclastic differentiation in RAW264.7 cells by estrogen and phytoestrogens. J Biol Chem 14: 13720-13727, 2005.

33. Shevde NK and Pike JW: Estrogen modulates the recruitment of myelopoietic cell progenitors in rat through a stromal cellindependent mechanism involving apoptosis. Blood 87 : 2683-2692, 1996.

34. Fiorelli G, Gori F, Petilli M, Tanini A, Benvenuti S, Serio M, Bernabei $\mathrm{P}$ and Brandi ML: Functional estrogen receptors in a human preosteoclastic cell Line. Proc Natl Acad Sci USA 92: 2672-2676, 1995.

35. Cao 1, Bu R, Oakley JI, Kalla SE and Blair HC: Estrogen receptor-beta modulates synthesis of bone matrix proteins in human osteoblast-like MG63 cells. J Cell Biochem 89: 152-164, 2003.

36. Bord S, Ireland DC, Beavan SR and Compston JE: The effects of estrogen on osteoprotegerin, RANKL, and estrogen receptor expression in human osteoblasts. Bone 32: 136-141, 2003. 